\title{
Centipedes from urban areas in southwestern Siberia, Russia (Chilopoda). Part 2. Geophilomorpha
}

\author{
Губоногие многоножкии урбанизированных территорий юга \\ Западной Сибири, Россия (Chilopoda). Часть 2. Geophilomorpha
}

\author{
P.S. Nefediev ${ }^{1}$ I.H. Tuf ${ }^{2}$, G.Sh. Farzalieva ${ }^{3}$ \\ П.С. Нефедьев ${ }^{1}$, И.Х. Ту $\phi^{2}$, Г.Ш. Фарзалиева ${ }^{3}$
}

${ }^{1}$ Altai State University, Lenin Avenue, 61, Barnaul 656049 Russia. E-mail: p.nefediev@mail.ru
${ }^{2}$ Palacký University, Šlechtitelù, 27, Olomouc 77900, Czech Republic. E-mail: ivan.tuf@upol.cz
${ }^{3}$ Perm State University, Bukireva Street, 15, Perm 614600 Russia. E-mail: g.farzalieva@yandex.ru
${ }^{1}$ Алтайский государственный университет, проспект Ленина, 61, Барнаул 656049 Россия.
${ }^{3}$ Пермский государственный национальный исследовательский университет, ул. Букирева, 15, Пермь 614600 Россия.

KEY WORDS: Geophilidae, Schendylidae, anthropochore, faunistics, introduction, Siberia.

КЛЮЧЕВЫЕ СЛОВА: Geophilidae, Schendylidae, антропохор, фаунистика, интродуцент, Сибирь.

ABSTRACT. The geophilomorph centipede fauna of urban areas in southwestern Siberia comprises at least seven species belonging to four genera and two families. The following records are new to western Siberia (Geophilus flavus (De Geer, 1778)) or southwestern Siberia (G. proximus C.L. Koch, 1847 and Pachymerium ferrugineum (C.L. Koch, 1835)). The northernmost range limits are reported for Arctogeophilus macrocephalus Folkmanová et Dobroruka, 1960, Escaryus japonicus Attems, 1927 and E. koreanus Takakuwa, 1937, all lying in western Siberia. The distributions of all relevant species encountered in the region are mapped.

РЕЗЮМЕ. Фауна многоножек-землянок урбанизированных территорий юга Западной Сибири включает как минимум семь видов, принадлежащих четырем родам и двум семействам. Указанные ниже находки оказались новыми: Geophilus flavus (De Geer, 1778) для Западной Сибири; G. proximus C.L. Koch, 1847 и Pachymerium ferrugineum (C.L. Koch, 1835) для юга Западной Сибири. Отмечена северная граница ареала для Arctogeophilus macrocephalus Folkmanová et Dobroruka, 1960, Escaryus japonicus Attems, 1927 и E. koreanus Takakuwa, 1937 в Западной Сибири. Даны карты с распространением всех видов в указанном регионе.

\section{Introduction}

This paper continues our review of the centipede fauna of urban habitats in southwestern Siberia, Russia [Nefediev et al., 2016b, c, d]. Despite all recent progress in the investigation of geophilomorph centipedes in the European part of Russia [Farzalieva, 2008; Volkova, 2014a, b, 2016; Zuev, 2016], the fauna of Geophilomor- pha in western Siberia, Asian Russia [Stuxberg, 1876; Sseliwanoff, 1881, 1884; Byzova, Chadaeva, 1965; Kozlovskaya, 1965; Titova, 1969, 1972a, b, 1975; Poryadina, 1991; Gerasko, Kolesnichenko, 1997; Nefediev, 2001; Striganova, Poryadina, 2005; Sergeeva, 2010, 2013, 2014, 2015; Bukhkalo, Sergeeva, 2012; Bukhkalo et al., 2014] remains understudied. To date, based on the literature data, the geophilomorph fauna of the Asian part of Russia comprises at least 26 species with the greatest species diversity observed in the Russian Far East (21 species), followed first by western and eastern Siberia (about 9 species), and then the mountains of southern Siberia (=Altais) ( 5 species). This can only be related to the latter territory still being poorly studied. Its geophilomorph fauna seems to be especially similar to those of eastern Siberia and the Russian Far East.

The material treated herein has mainly been deposited in the collection of the Altai State University, Barnaul, Russia (ASU), partly shared also with the collections of the Palacký University, Olomouc, Czech Republic (PUO) and of the Zoological Museum of the Lomonosov Moscow State University, Moscow, Russia (ZMUM), as indicated in the text. Literature references to the species concern western Siberia only.

Taxonomic part

ORDER GEOPHILOMORPHA

Family GEOPHILIDAE

Arctogeophilus macrocephalus Folkmanová et Dobroruka, 1960

Map 1.

? Arctogeophilus sp.: Byzova, Chadaeva, 1965: 337. 
Arctogeophilus macrocephalus Folkmanová et Dobroruka, 1960: Zalesskaja et al., 1982: 189.

MATERIAL EXAMINED (17 specimens from 2 localities). 8 ind. (ASU), 4 ind. (ZMUM), Russia, southwestern Siberia, Tomsk Area, Tomsk, Irkutskii Tract, glade in Betula forest, 20.07.1999, leg. P.S. Nefediev; 5 ind. (ASU), Russia, southwestern Siberia, Altai Province, Pervomaiskii District, Bobrovka, Pinus sylvestris forest with Betula, 20.08.1999, leg. A.V. Udaloy.

DISTRIBUTION. Being originally described by Folkmanová and Dobroruka [1960] from the Tatar Republic (= Tatarstan), European Russia, A. macrocephalus is highly widespread, ranging from the European part of Russia through Siberia to the mainland Russian Far East and Sakhalin Island [Zalesskaja et al., 1982]. The records of $A$. macrocephalus from the Asian part of Russia have previously been known from western Siberia in the Kemerovo Area and the Altai State Nature Reserve, Republic of Altai [Byzova, Chadaeva, 1965; Zalesskaja et al., 1982]; from eastern Siberia in the Krasnoyarsk Province [Vorobiova, 1999; Rybalov, 2002; Vorobiova et al., 2002]; and from the Russian Far East in the Jewish Autonomous Area, the Khabarovsk and Maritime provinces, the Chukotka Autonomous Area and the Sakhalin Area (southern Sakhalin Island) [Zalesskaja et al., 1982].

REMARKS. This species has hitherto been recorded neither from the Tomsk Area nor from the Altai Province, both southwestern Siberia. The former record is the northernmost range limit of its distribution in western Siberia. According to Zalesskaja et al. [1982], A. macrocephalus can prove to be a junior synonym of A. sachalinus Verhoeff, 1934 and A. attemsi Folkmanová, 1956, both of these in their turn possibly junior subjective synonyms of $A$. glacialis Attems, 1909, from Alaska, USA. Re-examination of type materials, as well as barcoding might be the proper tools to resolve these problems.

\section{Geophilus proximus C.L. Koch, 1847 Map 2.}

Geophilus proximus C.L. Koch, 1847: Sseliwanoff, 1881: 6-7, 1884: 87-89; Titova, 1969: 165; Poryadina, 1991: 14; Striganova Poryadina, 2005: 130; Bukhkalo, Sergeeva, 2012: 61; Sergeeva, 2013: 530-532; 2014: 72; Bukhkalo et al., 2014: 73-74.

MATERIAL EXAMINED (230 specimens: 136 o9, 94 juveniles from 13 localities). 3 + (PUO), Russia, southwestern Siberia, Tomsk Area, Tomsk, "Lagernyi Sad" Park, Betula, 17.05.2004; 2 우 (PUO), same Area, Tomsk, "Buff-Sad" Park, Acer and Populus, 15.05.2008; 3 우, 2 juv. (ASU), Russia, southwestern Siberia, Altai Province, Biysk, Sorokino, Malus stands on the bank of Biya River, litter,11.10.2009; 1 (ASU), same locality, Populus stands, under bark of cut trees, 19.10.2009; 3 juv. (ASU), same Province, Pervomaiskii District, Beriozki Railway Station, open man-made grounds, 12.06.2010; 1 क (PUO), same locality, 7.06 2014; 7 क०, 2 juv. (ASU), same locality, 3-20.09.2014; 1 juv. (ASU), same locality, 11.05.2015; all leg. P.S. Nefediev; 1 (PUO), same Province, Barnaul, Avalman, summer 2013, leg. V.M. Mamina; 8 OO , 4 juv. (PUO), same Province, Barnaul, Yuzhnyi, South Siberian Botanical Garden, open man-made grounds, 19.06.2013, leg. P.S. Nefediev, Yu.V. Dyachkov; 2 우 (PUO), same locality, 27.09.2013, leg. Yu.V. Dyachkov; 6 oo, 6 juv., (ASU), same Province, Barnaul, "Nagornyi" Park, soil samples (0-10 cm deep), June 2014; 2 우, 2 juv. (ASU), same locality, soil samples (10-20 cm deep), June 2014; 4 juv. (ASU), same Province, Barnaul, "Lesnaya Skazka" Park, hand sampling, June-July 2014; 6 juv. (ASU), same locality, soil samples (0-10 cm deep), June-July 2014; 1 , 4 juv. (ASU), same locality, soil samples (10-20 cm deep), JuneJuly 2014; 27 우, 4 juv. (ASU), same Province, Barnaul, "Izumrudnyi" Park, hand sampling, June 2014; 26 우, 8 juv. (ASU), same locality, soil samples (litter), June 2014; 18 우, 38 juv. (ASU), same locality, soil samples (0-10 cm deep), June 2014; 3 juv. (ASU), same locality, soil samples (10-20 cm deep), June 2014; 2 +9, 5 juv. (ASU), same Province, Barnaul, "Yubileinyi" Park, soil samples (0-10 cm deep), June 2014; 1 q, 3 juv. (ASU), same locality, soil samples (10-20 cm deep), June 2014, all leg. A.A. Streltsova; 4 + (ASU), same Province, Blagoveschenka District, Glyaden, Acer and Populus woodland belt, 10-14.08.2014, leg. A. Polyakov; 14 q० (ASU), 4 +क (ZMUM), same Province, Barnaul, "Lesnaya Skazka" Park, Acer and Betula, under planks, stones, in litter, 1.05.2015, leg. P.S. Nefediev; 1 (ASU), same Province, Romanovo District, Tambovskii, 19.08.2015, leg. I.K. Tyutyunnik; 3 우 (PUO), Russia, southwestern Siberia, Novosibirsk Area, Novosibirsk, Pervomaiskii Square, flower beds with bushes, 29.05.2014, leg. P.S. Nefediev.

DISTRIBUTION. This northern European, eurytopic species is distributed across the northern part of the Palaearctic from northeastern Europe to Japan, while the real distribution in the southern European countries is hard to estimate because of numerous misidentifications in the past [Bonato et al., 2005]. Geophilus proximus is widespread across most of European Russia, ranging from the Murmansk Area in the north to the Rostov-on-Don Area in the south and to the Urals in the east [Farzalieva, 2008; Volkova, 2016]. In the Asian part of Russia, it has previously been recorded only from western Siberia [Sseliwanoff, 1881, 1884; Titova, 1969], the Tyumen Area [Poryadina, 1991; Striganova, Poryadina, 2005; Bukhkalo, Sergeeva, 2012; Sergeeva, 2013; Bukhkalo et al., 2014].

REMARKS. According to Zalesskaja et al. [1982], G. proximus tends to inhabit moderately humid soils, but Sergeeva [2013] noted its being a typical pedobiont that needs no litter, predominating in open, well heated sites. Zalesskaja et al. [1982] also suggested Schizotaenia ornata Folkmanová et Dobroruka, 1960 to be a junior synonym of G. proximus, despite the lack of information on the carpophagous structure in the original description [cf. Bonato, Minelli, 2014]. This is the most common geophilomorph centipede from urban areas in southwestern Siberia. The Siberian populations of this species are parthenogenetic like are those across most of European Russia. This species has hitherto been recorded neither from the Tomsk nor the Novosibirsk areas, nor the Altai Province, all in southwestern Siberia, where it dwells only in outdoor habitats such as city parks and open man-made grounds.

\section{Geophilus flavus (De Geer, 1778) Map 3.}

MATERIAL EXAMINED. 1 (ASU), Russia, southwestern Siberia, Tomsk Area, Tomsk, Siberian Botanical Garden, hothouse, 21.04.2000, leg. P.S. Nefediev.

DISTRIBUTION. An Euro-Siberian species distributed in the western Palaearctic, ranging from northwestern Africa through most of Europe to Siberia; also introduced to North America [Bonato et al., 2005]. However, in the Asian part of Russia a single specimen of this species that comes from a single locality has 


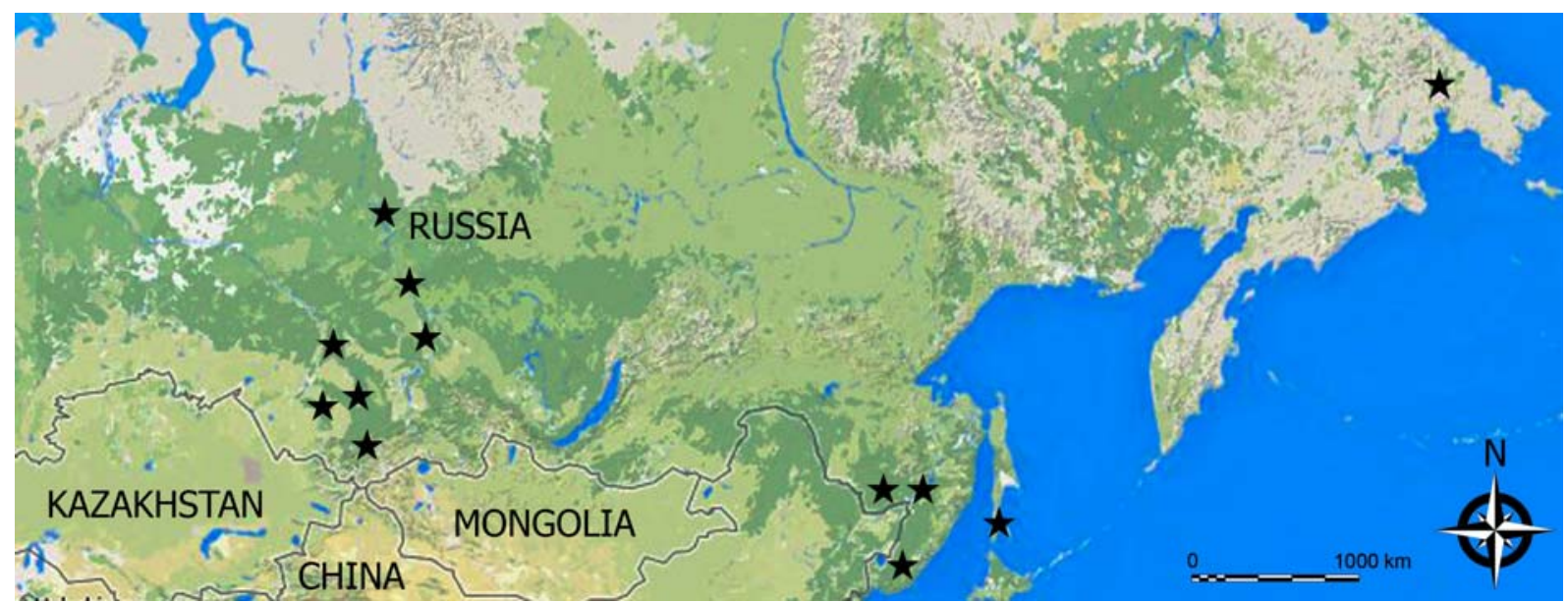

Map 1. Distribution of Arctogeophilus macrocephalus Folkmanová et Dobroruka, 1960 in Asian Russia (asterisk).

Карта 1. Распространение Arctogeophilus macrocephalus Folkmanová et Dobroruka, 1960 в азиатской России (звезда).

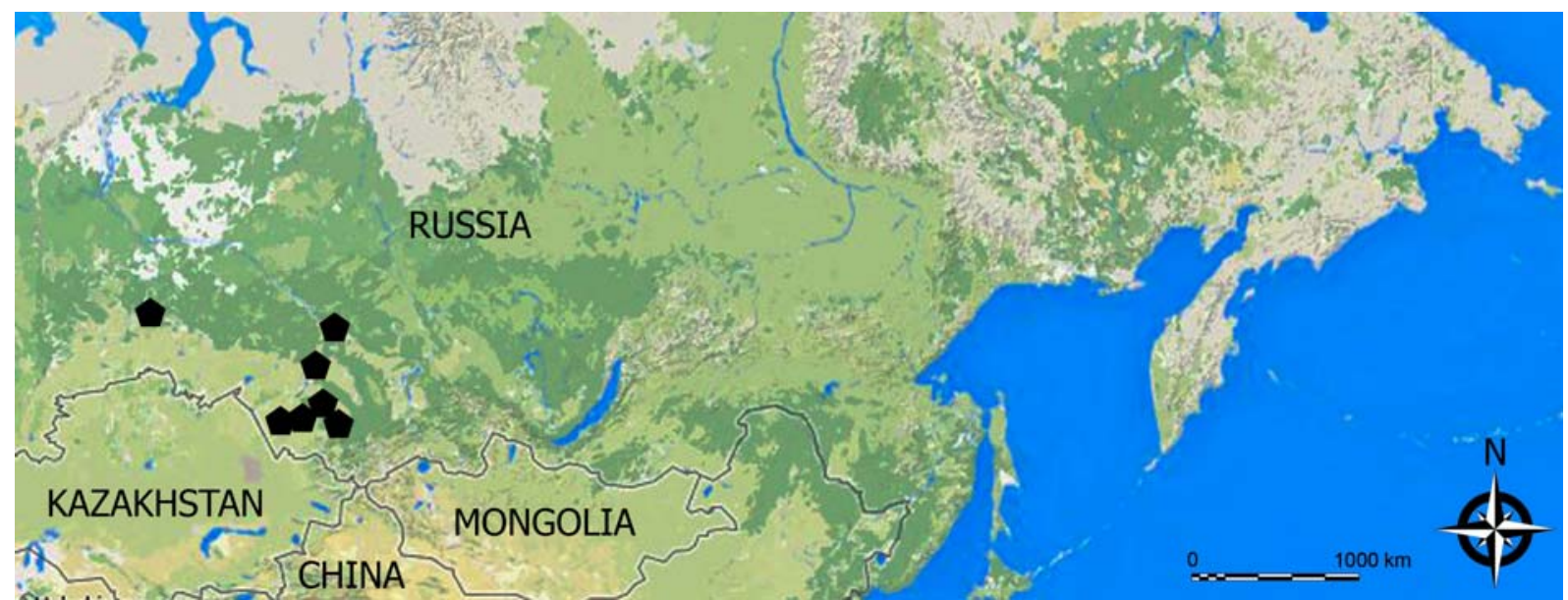

Map 2. Distribution of Geophilus proximus C.L. Koch, 1847 in Asian Russia (pentagon).

Карта 2. Распространение Geophilus proximus C.L. Koch, 1847 в азиатской России (пятиугольник).

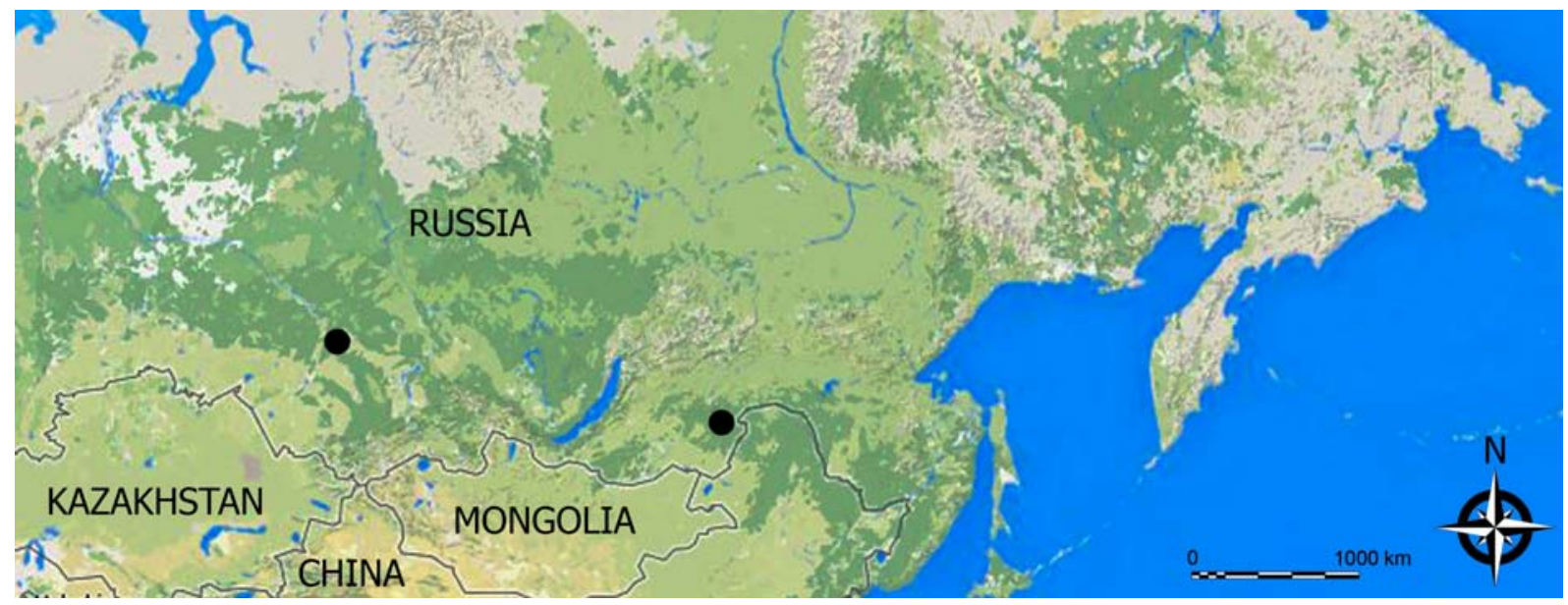

Map 3. Distribution of Geophilus flavus (De Geer, 1778) in Asian Russia (circle).

Карта 3. Распространение Geophilus flavus (De Geer, 1778) в азиатской России (круг). 
hitherto been known, referred to as a junior subjective synonym of Arthronomalus longicornis Leach, 1815, from the environs of the village of Shilkinskii Zavod, Zabaikalskii Province, eastern Siberia [see Gerstfeldt, 1859].

REMARKS. This is the first record of G. flavus in western Siberia. Its absence from almost all previously known faunistic papers (except Gerstfeldt [1859]), coupled with the above record from a hothouse in the Siberian Botanical Garden, may indicate its anthropochore introduction east of the Urals. The published synonymy of $S$. ornata under G. flavus by Bonato and Minelli [2014] implies that there may be some previous records of $G$. flavus from the former USSR reported under the name of G. proximus [see Zalesskaja et al., 1982].

\section{Pachymerium ferrugineum (C.L. Koch, 1835) Map 4.}

Pachymerium ferrugineum (C.L. Koch, 1835): Sergeeva, 2013: 530-532; Bukhkalo et al., 2014: 73.

MATERIAL EXAMINED (17 specimens: $1 \sigma^{\gamma}, 9$ 우, 7 juveniles from 2 localities). 1 (ASU), Russia, southwestern Siberia, Tomsk Area, Tomsk, Siberian Botanical Garden, hothouses, 10.12.1999; 2 우, 1 juv. (ASU), 2 ㅇ (ZMUM), same locality, 3.03.2000; $1 \sigma^{7}, 3$ 우 (ASU), same locality, 21.04.2000; 1 (ASU), same locality, 3.11.2005, all leg. P.S. Nefediev; 1 juv. (ASU), same locality, rose hothouse, pitfall traps, 28.03.14.04.2006, leg. P.S. Nefediev, A.M. Folin; 1 juv. (ASU), Russia, southwestern Siberia, Altai Province, Barnaul, OJSC "Dekorativnye kultury", houseplants hothouse No. 3, 22.12.2014; 1 juv. (ASU), same locality, rose hothouse No. 5, 22.12.2014; 1 juv. (ASU), same locality, seedling flowers hothouse No. 10, 26.12.2014; 2 juv. (ASU), same locality, rose hothouse No. 13, 24.12.2014, all V.M. Mamina.

DISTRIBUTION. A trans-Palaearctic polyzonal species that ranges across most of the western Palaearctic, from Macaronesia through Europe to Central Asia [Bonato et al., 2005]; also known, obviously as anthropochore introductions, from other parts of the world, e.g. the eastern states of the USA [Bonato et al., 2005; Volkova, 2016]. In Asian Russia, it has previously been reported from the Jewish Autonomous Area and Maritime Province in the Russian Far East [Zalesskaja et al., 1982], as well as from the Chelyabinsk, Sverdlovsk and Tyumen areas within western Siberia [Farzalieva, 2008; Sergeeva, 2013; Bukhkalo et al., 2014].

REMARKS. This species prefers dry, xerophyte habitats such as upland meadows, cultivated fields and pine forests [Zalesskaja et al., 1982; Sergeeva, 2013]. It has hitherto been recorded neither from the Tomsk Area nor from the Altai Province, both southwestern Siberia, where $P$.ferrugineum has been found dwelling only in indoor anthropogenic habitats, i.e. hothouses.

\section{Family SCHENDYLIDAE}

\section{Escaryus japonicus Attems, 1927 Map 5.}

Escaryus japonicus Attems, 1927: Byzova, Chadaeva, 1965: 337; Titova, 1972a: 135; 1972b: 113-114; Pereira, Hoffman, 1993: 9.
MATERIAL EXAMINED (18 specimens: $7 \sigma^{7} \sigma^{7}, 8$ o 9,3 juveniles from 2 localities). $5 \sigma^{\top} \sigma^{\top}, 2$ $9+, 3$ juv. (ASU), $2 \sigma^{\top} \sigma^{\top}, 2$ 우 (ZMUM), Russia, southwestern Siberia, Tomsk Area, Tomsk District, Molodiozhnyi, potato field, 8.09.1999; 4 우 (ASU), same Area, ca $10 \mathrm{~km} \mathrm{~N}$ of Tomsk, "Tomskneftekhim", near Acetylene Plant, Populus tremula, 4.05.2003, all leg. P.S. Nefediev.

DISTRIBUTION. An Eurasian species ranging from Japan through the Russian Far East and Siberia to the middle and southern Urals and the middle Volga region [Farzalieva, 2008; Volkova, 2016], also known from northern China [Takakuwa, Takashima, 1949]. In Asian Russia, it has previously been reported from the Russian Far East in Sakhalin Island, the Maritime Province and Cisamuria, and from western Siberia in the Kemerovo Area and the Altais [Byzova, Chadaeva, 1965; Titova, 1972a]; the record of E. japonicus from the middle flow of Yenisei River, Krasnoyarsk Province [Vorobiova, 1999] is doubtful (omitted from Map 5) because two different species of Escaryus have since been identified and published from the same material [Rybalov, 2002: 83; Vorobiova et al., 2002: 62].

REMARKS. This species has hitherto not been reported from the Tomsk Area, southwestern Siberia, where it marks the northernmost range limit of its distribution in Siberia.

\section{Escaryus koreanus Takakuwa, 1937 Map 6.}

Escaryus koreanus Takakuwa, 1937: Titova, 1972a: 135; 1972b: 112-113; Pereira, Hoffman, 1993: 9.

MATERIAL EXAMINED (14 specimens: $3 \sigma^{\top} \sigma^{\top}, 3$ o 9,8 juveniles from 4 localities). $1 \sigma^{7}, 1$, 8 juv. (ASU), 1 (ZMUM), Russia, southwestern Siberia, Tomsk Area, Tomsk, Siberian Botanical Garden, hothouses, 3.03.2000; 1 O (ASU), same Area, Tomsk, Universitetskaya Roshcha, Betula, 23.04.2002; $1 \sigma^{7}$ (ASU), same Area, Tomsk, Michurina Street, Populus tremula forest, 2.11.2005; 1 $\sigma^{7}$ (ASU), same Area, Tomsk, "Buff-Sad" Park, Acer and Populus, 15.05.2008, all leg. P.S. Nefediev.

DISTRIBUTION. Originally described by Takakuwa [1937] from the Korean Peninsula, in the Asian part of Russia E. koreanus has hitherto been recorded from the Kemerovo Area [Titova, 1972a, b] and the Altais [Titova, 1972a], both western Siberia, from the Yenisei River Basin in the Krasnoyarsk Province, eastern Siberia [Rybalov, 2002; Vorobiova et al., 2002], and from the Maritime Province and Cisamuria, Russian Far East [Titova, 1972a, b].

REMARKS. This species has hitherto not been recorded from the Tomsk Area, southwestern Siberia, where it marks the northernmost range limit of its distribution in western Siberia, while in eastern Siberia the species inhabits even the northern taiga belt [Rybalov, 2002; Vorobiova et al., 2002].

\section{Escaryus retusidens Attems, 1904 Map 7.}

Escaryus retusidens Attems, 1904: Titova, 1972a: 135; 1972b: 110-111; Pereira, Hoffman, 1993: 9.

MATERIAL EXAMINED (4 specimens: $3 \sigma^{\top} \sigma^{\top}, 1$ juv. from 2 localities). $2 \sigma^{\top} \sigma^{\top}$ (ASU), $1 \sigma^{\top}$ (ZMUM), Russia, southwestern Siberia, Altai Province, Smolenskoe District, Smolenskoe, Poperechnaya River, Populus, 21.04.2013, leg. P.S. Nefediev, J.S. 


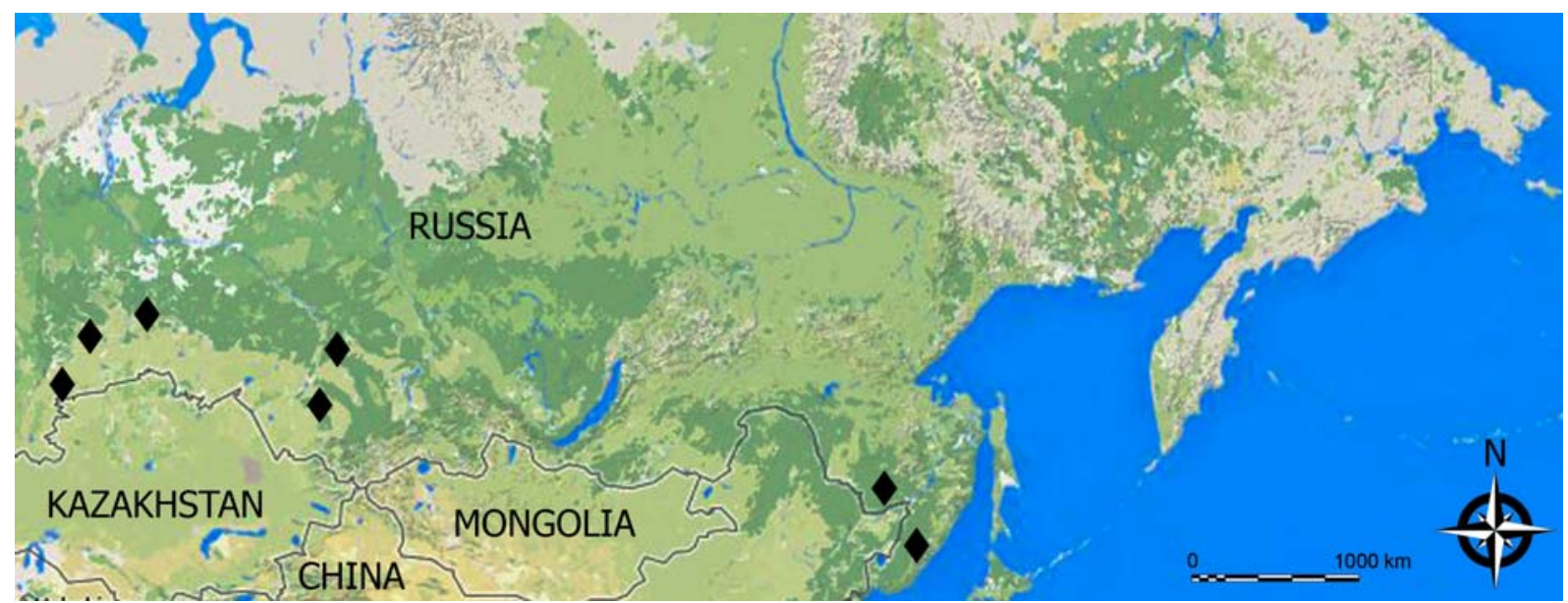

Map 4. Distribution of Pachymerium ferrugineum (C.L. Koch, 1835) in Asian Russia (diamond).

Карта 4. Распространение Pachymerium ferrugineum (C.L. Koch, 1835) в азиатской России (ромб).

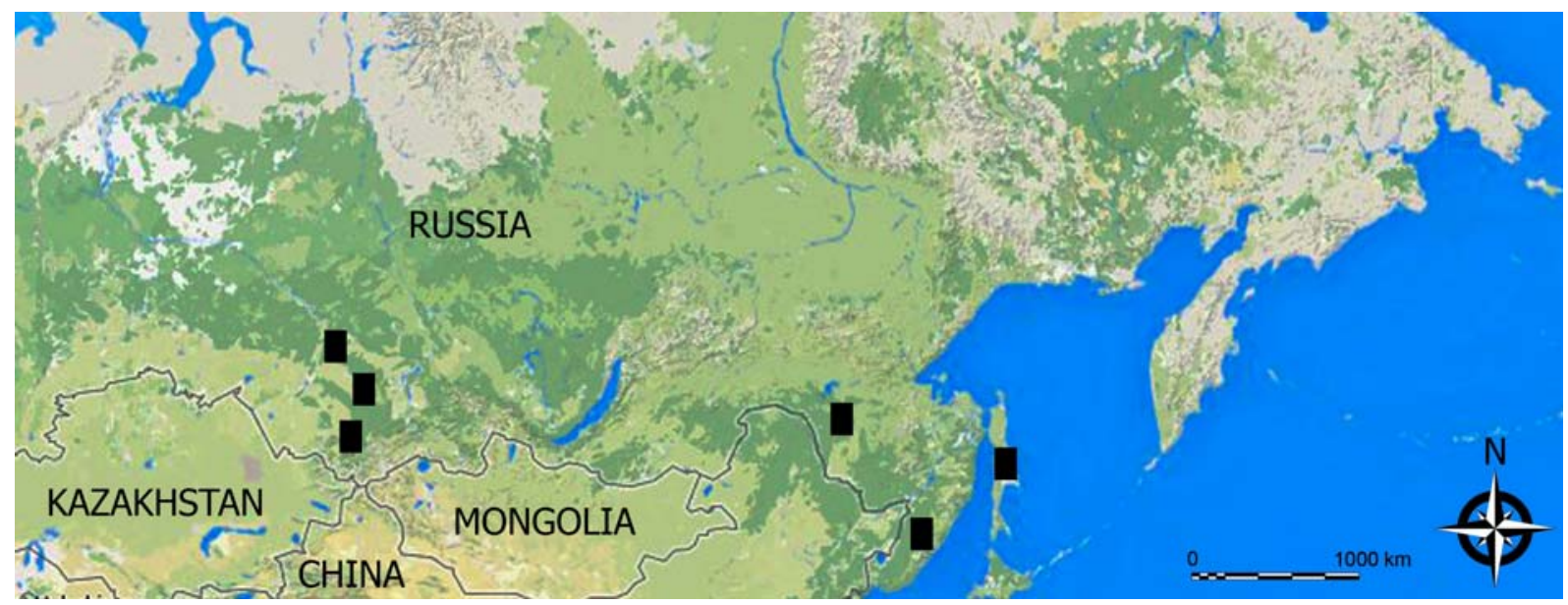

Map 5. Distribution of Escaryus japonicus Attems, 1927 in Asian Russia (rectangle).

Карта 5. Распространение Escaryus japonicus Attems, 1927 в азиатской России (прямоугольник).

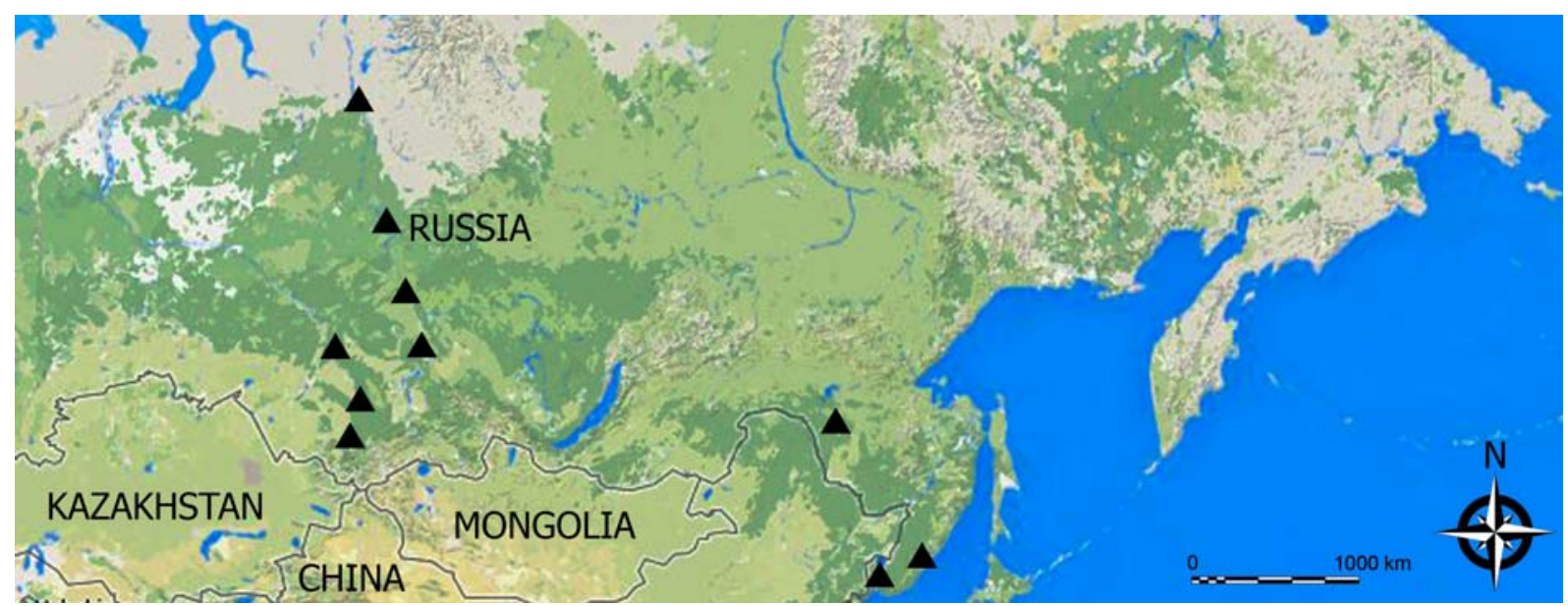

Map 6. Distribution of Escaryus koreanus Takakuwa, 1937 in Asian Russia (triangle).

Карта 6. Распространение Escaryus koreanus Takakuwa, 1937 в азиатской России (треугольник). 


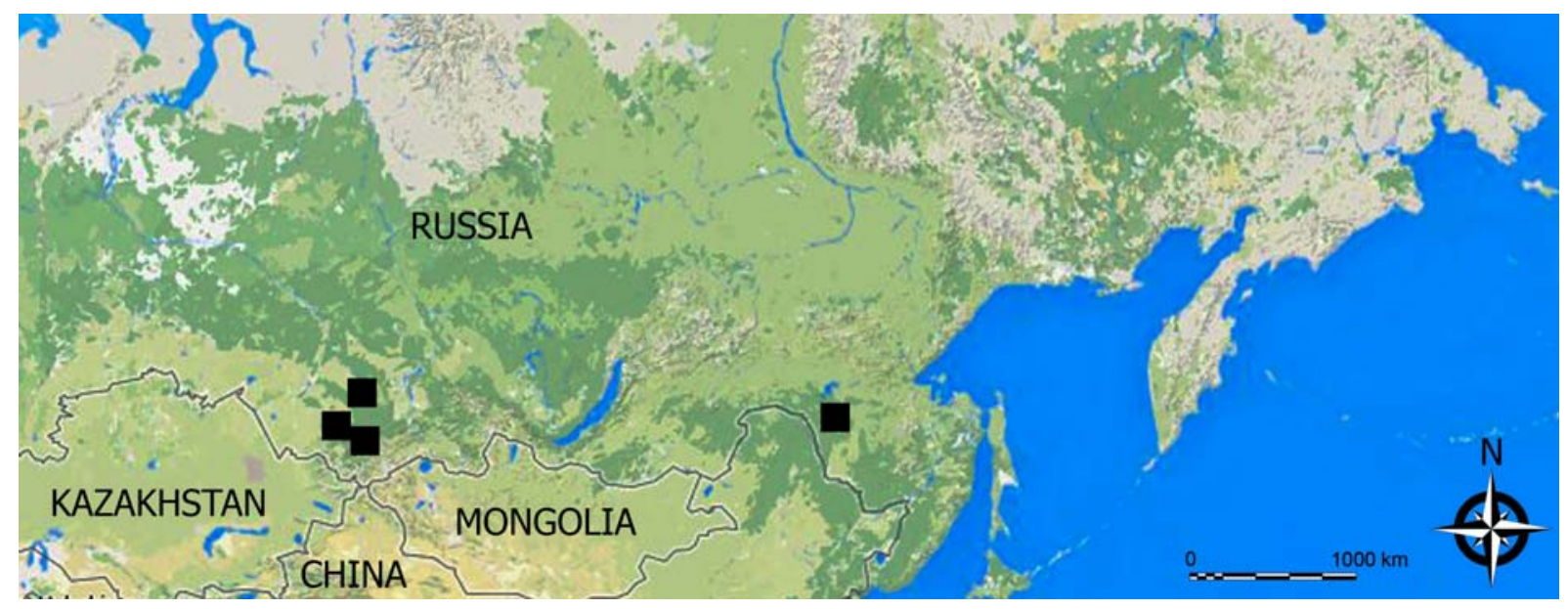

Map 7. Distribution of Escaryus retusidens Attems, 1904 in Asian Russia (square).

Карта 7. Распространение Escaryus retusidens Attems, 1904 в азиатской России (квадрат).

Nefedieva; 1 juv. ( $\sigma^{7}$ sad) (ASU), same Province, Biysk, Odintsovka, Salix along brook, 19.04.2009, leg. P.S. Nefediev.

DISTRIBUTION. Being originally described from Central Asia, i.e. Przhevalsk (now Karakol) in Kyrgyzstan, E. retusidens is highly widespread, in the former USSR ranging from Moldova, Ukraine, the Crimean Peninsula, the northern Caucasus and the central part of European Russia in the west, through the Kuznetsk Coal Basin (= Kuzbass) and the Altais in western Siberia, to Cisamuria in the east, also reported from the Ile Alatau and Dzungarsky Alatau mountains in eastern Kazakhstan [Titova, 1972a].

REMARKS. The present first records of E. retusidens from the Altai Province show that this rare species tends to dwell in rather weakly disturbed habitats rather than highly urbanized areas.

\section{Conclusions}

To date, at least seven species from four genera and two families of Geophilomorpha are known to occur in urban areas in southwestern Siberia, Russia. Geophilus flavus (De Geer, 1778) appears to be new to the fauna of western Siberia. Two species, G. proximus C.L. Koch, 1847 and Pachymerium ferrugineum (C.L. Koch, 1835 ), are formally recorded in southwestern Siberia for the first time. The former species is the most abundant and widespread geophilomorph in the study area. Arctogeophilus macrocephalus Folkmanová et Dobroruka, 1960, Escaryus japonicus Attems, 1927 and E. koreanus Takakuwa, 1937 show the northernmost range limits of their distribution areas in western Siberia. Most of the study geophilomorph species inhabit city parks, botanical gardens and open man-made grounds in southwestern Siberia, being widespread across Eurasia and representing natural components in the centipede fauna of the investigated area. However, urban scutigeromorph, scolopendromorph and lithobiomorph centipedes [Nefediev et al., 2016b, c, d], as well as urban millipedes [Nefediev et al., 2013, 2014, 2016a] recorded from southwestern Siberia are mainly related to anthropochore introductions.

ACKNOWLEDGEMENTS. We are most grateful to S.I. Golovatch (Moscow, Russia) who kindly checked the English of an advanced draft. Our deepest gratitude extends to all collectors who donated us their material for study. Special thanks are also addressed to E. Stöckli (Basel, Switzerland) and R.V. Zuev (Stavropol, Russia) who provided us with some obscure literature.

\section{References}

Bonato L., Minelli A. 2014. Chilopoda Geophilomorpha of Europe: a revised list of species with taxonomic and nomenclatural notes // Zootaxa. Vol.3770. No.1. P.1-136.

Bonato L., Minelli A., Spunggis V. 2005. Geophilomorph centipedes of Latvia (Chilopoda, Geophilomorpha) // Latvijas entomologs. Vol.42. No.1. P.5-17.

Bukhkalo S.P., Galitch D.E., Sergeeva E.V., Vazhenina N.V. 2014. [Synopsis of the invertebrate fauna of the southern taiga in western Siberia (the basin of the Lower Irtysh)]. Moscow: KMK Scientific Press. 189 p. [in Russian].

Bukhkalo S.P., Sergeeva E.V. 2012. [Interannual dynamics of the composition and structure of soil invertebrate communities in the root terrace of the Irtysh] // Belgorod State University Scientific Bulletin. Natural sciences. No.15(134). Issue 20. P.59-64 [in Russian, with English summary].

Byzova Yu.B., Chadaeva Z.V. 1965. [A comparative characteristic of the soil fauna of various associations in the Abies sibirica forest (Kemerovo Area)] // Zoologicheskii Zhurnal. T.44. No.3. P.331-339 [in Russian, with English summary].

Farzalieva G.Sh. 2008. [The fauna and chorology of Myriapoda from the Urals and Cisuralia]. Thesis of Candidate (Ph.D.) of Biological Sci. Degree. Perm State University. 189 p. [in Russian].

Gerasko L.I., Kolesnichenko L.G. 1997. [Soil macrofauna in cedar (Pinus sibirica) biocenoses of the subtaiga zone in western Siberia] // Pochvovedenie. No.4. P.510-517 [in Russian, with English summary].

Gerstfeldt G. 1859. Ueber einige zum Theil neue Arten Platoden, Anneliden, Myriapoden und Crustaceen Sibiriens, namentlich seines östlichen Theiles und des Amur-Gebiets // Mémoires de l'Académie Impériale des Sciences. St. Pétersbourg. T.8. S.1-36. 
Kozlovskaya L.S. 1965. [Fauna of swampy forest soils in the $\mathrm{Ob}$ and Tom interfluve] // Osobennosti bolotoobrazovaniya v nekotorykh lesnykh i predgornykh raionakh Sibiri i Dalnego Vostoka. Moscow: Nauka Publ. P.141-164 [in Russian].

Nefediev P.S. 2001. [On the fauna and ecology of Myriapoda in the environs of the village of Smolenskoe, Altai Province] // Landshafty Zapadnoi Sibiri: problemy issledovanii, ekologiya i ratsionalnoe ispolzovanie. Materialy VII Mezhdunarodnoi mezhvuzovskoi konferentsii, posvyashchionnoi Dnyu Zemli. Biysk: Biysk Pedagogical State University Publ. P.84-86 [in Russian].

Nefediev P.S., Kocourek P., Nefedieva J.S. 2016a. The first record of Polydesmus inconstans Latzel, 1884 (Diplopoda: Polydesmida: Polydesmidae) in the Asian part of Russia // Arthropoda Selecta. Vol.25. No.1. P.19-21.

Nefediev P.S., Nefedieva J.S., Dyachkov Yu.V. 2013. Review of the millipede genus Cylindroiulus Verhoeff, 1894 in the Asian part of Russia (Diplopoda: Julida: Julidae) // Arthropoda Selecta. Vol.22. No.4. P.339-342.

Nefediev P.S., Nefedieva J.S., Dyachkov Yu.V. 2014. A review of the anthropochore millipede fauna of Asian Russia, with new records from the Altai Province, Siberia (Diplopoda) // Arthropoda Selecta. Vol.23. No.4. P.337-345.

Nefediev P.S., Tuf I.H., Dyachkov Yu.V. 2016è. First record of Cryptops (Cryptops) hortensis (Donovan, 1810) in southwestern Siberia, Russia (Chilopoda: Scolopendromorpha: Cryptopidae) // Biological Bulletin of Bogdan Chmelnitskiy Melitopol State Pedagogical University. Vol.6. No.2. P.107-109. DOI: $10.15421 / 201642$

Nefediev P.S., Tuf I.H., Dyachkov Yu.V., Efimov D.A. 2016ñ First records of Scutigera coleoptrata (Linnaeus, 1758) in the south of western Siberia, Russia (Chilopoda: Scutigeromorpha: Scutigeridae) // Biological Bulletin of Bogdan Chmelnitskiy Melitopol State Pedagogical University. Vol.6. No.1. P.428-432. DOI: $10.15421 / 201626$.

Nefediev P.S., Tuf I.H., Farzalieva G.Sh. 2016d. Centipedes from urban areas in southwestern Siberia, Russia (Chilopoda). Part 1. Lithobiomorpha // Arthropoda Selecta. Vol.25. No.3. P.257266.

Pereira L.A., Hoffman R.L. 1993. The American species of Escary$u s$, a genus of Holarctic centipeds (Geophilomorpha: Schendylidae) // Jeffersoniana. Vol.3. P.1-72.

Poryadina N.M. 1991. [Mesofauna of forest soils in the Western Siberian Plain]. Autoreferate of the Thesis of Candidate (Ph.D.) of Biological Sci. Degree. Tomsk: Tomsk State University Publ. 21 p. [in Russian]

Rybalov L.B. 2002. [Zonal and landscape changes in soil invertebrate populations in a near-Yenisei River region of middle Siberia and the role of temperature adaptations in the meridional (zonal) distribution of invertebrates] // Russian Entomological Journal. Vol.11. No.1. P.77-86 [in Russian, with English summary].

Sergeeva E.V. 2010. [Population dynamics of soil-dwelling invertebrates in grassy communities from the southern taiga of western Siberia] // Belgorod State University Scientific Bulletin. Natural sciences. No.9(80). Issue11. P.65-72 [in Russian, with English summary]

Sergeeva E.V. 2013. [Biotopic distribution and the numbers of centipedes (Chilopoda) in the Irtysh Valley of western Siberia, Russia] // Euroasian Entomological Journal. Vol.12. No.6. P.529-533 [in Russian, with English summary].

Sergeeva E.V. 2014. [Species diversity of soil invertebrate communities in the Irtysh root terrace] // Belgorod State University
Scientific Bulletin. Natural sciences. No.17(188). Issue28. P.7075 [in Russian, with English summary].

Sergeeva E.V. 2015. [Seasonal dynamics in the composition and structure of soil macrofauna in Irtysh root terrace communities] // Sovremennye problemy nauki i obrazovaniya. No.6 [in Russian, with English summary].

Sseliwanoff A.V. 1881. [Geophilidae from the Museum of Imperial Academy of Sciences] // Zapiski Imperatorskoi Akademii Nauk. Vol.40. P. 1-27 [in Russian].

Sseliwanoff A.V. 1884. [Materials towards the study of Russian myriapods] // Trudy Russkogo Entomologicheskogo Obshchestva. Vol.18. No.1-2. P.69-121 [in Russian].

Striganova B.R., Poryadina N.M. 2005. [Soil animal population in boreal forests of the West Siberian Plain]. Moscow: KMK Scientific Press Ltd. 234 p. [in Russian].

Stuxberg A. 1876. Myriopoder från Sibirien och Waigatsch ön samlade under Nordenskiöldska expeditionen 1875 // Öfversigt af Kongliga Vetenskaps-Akademiens Förhandlingar. Årg.33. No.2. S.11-38.

Takakuwa Y. 1937. Eine neue Escaryus-Art aus Korea // Zoological Magazine. Vol.49. P.297-299.

Takakuwa Y., Takashima H. 1949. Myriapods collected in Shansi, North China // Acta Arachnologica. Vol.11, No.1-2. P.51-69 [in Japanese, with English summary].

Titova L.P. 1969. [Geophilids of the USSR fauna and news in the distribution of the fam. Mecistocephalidae] // M.M. Aleinikova (ed.). Problemy pochvennoi zoologii. Materialy Tretiego Vsesoyuznogo soveshchaniya. Kazan, 1969. Moscow: Nauka Publ. P.165-166 [in Russian].

Titova L.P. 1972a. [Pattern of the distribution of the genus Escaryus (Chilopoda) in the USSR] // M.S. Ghilarov (ed.). Problemy pochvennoi zoologii. Materialy Chetvertogo Vsesoyuznogo soveshchaniya. Baku, 1972. Moscow: Nauka Publ. P.135-136 [in Russian].

Titova L.P. 1972b. [New species of the genus Escaryus Cook et Collins (Schendylidae, Chilopoda)] // M.S. Ghilarov (Ed.). Ekologiya pochvennykh bespozvonochnykh. Moscow: Nauka Publ. P.94-119 [in Russian].

Volkova Yu.S. 2016. [An annotated catalogue of geophilomorph centipedes (Chilopoda, Geophilomorpha) from the European part of Russia] // Zoologicheskii Zhurnal. T.95. No.6. P.669678 [in Russian, with English summary].

Vorobiova I.G. 1999. [Ecological and faunistic characteristics of myriapod populations in the mid-flow region of Yenissei River] // Problemy pochvennoi zoologii. Materialy II (XII) Vserossiiskogo soveshchaniya po pochvennoi zoologii. Moscow: KMK Press. P.33-34 [in Russian].

Vorobiova I.G., Rybalov L.B., Rossolimo T.E., Zalesskaja N.T. 2002. [Zonal and landscape distribution of the myriapod fauna and populations (Myriapoda) in the Yenisei River basin] // Izuchenie, sokhranenie i vosstanovlenie bioraznoobraziya ekosistem na Yeniseiskom ekologicheskom transekte: Zhivotnyi mir, etno-ekologicheskie issledovniya, 2. Moscow: IEE RAS Publ. P.60-71 [in Russian].

Zalesskaja N.T., Titova L.P., Golovatch S.I. 1982. [The myriapod fauna of the Moscow Region] // M.S. Ghilarov (ed.). Pochvennye bespozvonochnye Moskovskoi oblasti. Moscow: Nauka Publ. P.179-200 [in Russian].

Zuev R.V. 2016. Centipedes (Chilopoda) from the Stavropol Territory, northern Caucasus, Russia // Arthropoda Selecta. Vol.25. No.1. P.23-38.

Responsible editor S.I. Golovatch 